\title{
SHORT COMMINICATION
}

\section{Involvement of gene expressions in apoptosis of vascular endothelial cells induced by rattlesnake venom}

\author{
Miao Jun Ying1, *, Satohiko Araki2, Yi Ren Han1, \\ Hiroshi Hayashi2 \\ 1 Institute of Developmental Biology, School of Life Science, \\ Shandong University, Jinan 250100, China \\ 2 Sugashima Marine Biological Laboratory, School of Science, \\ Nagoya University, Toba, Mie, 517 Japan
}

\begin{abstract}
Formation of apoptotic bodies is a typical character of apoptotic cell death, but how the processes are controlled is not known. In this study, we compared two apoptosis inducing systems in vascular endothelial cells (VEC). We found that the formation of apoptotic bodies during apoptosis induced by rattlesnake venom, which is an unique and specific apoptosis inducer to vascular endothelial cells, was much faster than that induced by deprivation of survival factors (aFGF and serum). When we blocked the synthesis of mRNAs in cells treated with rattlesnake venom by DRB (5, 6-dichloro-1- $\beta$-Dribofuranosylbenzimidazole), an inhibitor of transcription, the formation of apoptotic bodies was dramatically inhibited. We examined the expression of $\mathrm{P}^{53}$ gene and found that its expression was much higher in apoptosis induced by rattlesnake venom than that in apoptosis induced by deprivation of aFGF and serum. Our results suggest that gene expression is important and $\mathrm{P}^{53}$ gene may play a major role in inducing the formation of apoptotic bodies in VEC.
\end{abstract}

Key words: Apoptosis, rattlesnake venom, gene expressions, $P^{53}$ gene, endothelial cells.

\footnotetext{
* Corresponding author, e-mail: zhaobx@jn-public.sd.cninfo.net
} 
Gene expressions in apoptosis induced by rattlesnake venom

\section{INTRODUCTION}

Apoptosis is a pathway of cell death characterized by a series of specific morphological changes. The great majority of programmed cell death from insects to mammals exhibit striking consistent morphological features, typical for apoptosis, suggesting that a molecular machinery for cell death has been conserved in the animal kingdom. This machinery which is still largely uncharacterized, executes a series of changes in the cells resulting in the condensation of the nucleus, fragmentation of DNA and plasma membrane changes like the formation of apoptotic bodies (membrane bound vesicles)[1-5]. A recent report showed that cell death and the induction of the formation of apoptotic body might be regulated by distinct pathways in hepatocytes[6]. In our laboratory, apoptosis of vascular endothelial cells has been studied, and we found that formation of apoptotic bodies during apoptosis triggered by rattlesnake venom is much faster than that in apoptosis induced by deprivation of FGF and serum[7],[8]. However, the regulation process of the formation of apoptotic bodies is unknown till now. In this study, we examined gene expressions and the possible role of $\mathrm{P}^{53}$ gene in the formation of apoptotic bodies in human vascular endothelial cells induced by rattlesnake venom.

\section{MATERIAL AND METHODS}

\section{Reagents}

MCDB-104 medium was purchased from Kyokuto Pharmaceutical Industry, Tokyo, Japan. Fetal bovine serum (FBS) was purchased from Wako Pure Chemical Industry, Osaka, Japan. aFGF was extracted from bovine brains by the method of Lobb and Fett[9]. Rattlesnake venom was obtained commercially from Sigma Co., St. Louis, MO, USA. A Quick Prep mRNA Purification Kit was purchased from Pharmacia P-L Biochemicals Inc. Tokyo, Japan. Human P53 cDNA $(2.16 \mathrm{~kb})$ was obtained from Japanese Cancer Research Resources Bank (JCRB), Tokyo, Japan. A cDNA probe for the human gene for beta-actin was purchased from Wako Pure Chemical Industry, Osaka, Japan. A Random Primer DNA Labeling Kit was obtained commercially from Takara Industry, Otu, Japan. DRB (5, 6-dichloro-1- $\beta$-D-ribofuranosylbenzimidazole) was purchased from Funakoshi Inc., Tokyo, Japan. All other reagents were of ultra-pure grade.

\section{Cell culture and induction of apoptosis}

Human umbilical vein endothelial cells (HUVEC) were obtained by the method of Jaffe[10]. The cells were cultured on gelatin-coated plastic dish in MCDB-104 medium supplemented with $10 \% \mathrm{FBS}$ and $70 \mathrm{ng} / \mathrm{ml}$ aFGF (plus $100 \mu \mathrm{g} / \mathrm{ml}$ heparin) at $37^{\circ} \mathrm{C}$ in $5 \% \mathrm{CO}_{2}$ and $95 \%$ air. In all of our experiments, we used cells with a population doubling level of 10 to 20 . When the cells were grown until they became confluence, the medium was replaced by aFGF- and FBS- free MCDB104 medium after washing once with the same medium. The cells were kept in aFGF- and FBSfree MCDB-104 medium with or without venom. The number of trypsinized cells was counted by a Coulter counter after deprivation of survival factors or being treated with rattlesnake venom for $0 \mathrm{~h}, 2 \mathrm{~h}, 4 \mathrm{~h}, 6 \mathrm{~h}$, or $8 \mathrm{~h}$. But the detached cells were washed off before trypsin digestion. The cells which were unstained by erythrosin B $(0.5 \%$, Sigma) and kept attached to dishes after washing were regarded as living cells. Apoptosis (\%) was calculated by the following equation: apoptosis $(\%)=100 \mathrm{x}$ (total number of cells-number of viable cells)/total number of cells. 
Miao JY et al.

\section{Analysis of DNA fragmentation}

$2 \times 10^{6}$ cells were incubated in a digestion buffer that contained $200 \mu \mathrm{g} / \mathrm{ml}$ proteinase $\mathrm{K}$ at 50 ${ }^{\circ} \mathrm{C}$ for $5 \mathrm{~h}$. The cellular DNA was extracted once with phenol and once with a mixture of phenol, chloroform and 3-methyl-1-butanol (25:24:1, v/v). After digestion with RNase (final concentration, $600 \mu \mathrm{g} / \mathrm{ml}$ ) at $37^{\circ} \mathrm{C}$ for $30 \mathrm{~min}$, the sample was subjected to electrophoresis on a $2 \%$ agarose gel in Tris-acetate buffer ( $40 \mathrm{mM}$ Tris-acetate, $2 \mathrm{mM}$ EDTA, pH 8.0). The gel was then stained with ethidium bromide and photographed on a UV transilluminator.

\section{Nuclear fragmentation assay}

This experiment was performed according to the published method[11].

\section{Extraction of $m R N A$ and northern blot analysis}

Control cells and cells harvested after $3 \mathrm{~h}$ and $6 \mathrm{~h}$ of treatment with rattlesnake venom were washed twice in PBS and their respective mRNA was extracted and purified with a Quick Prep mRNA Purification Kit. Nucleolytic activity in the snake venom did not interfere with the preparation of mRNA, as judged by the yield of mRNA and its ability to hybridize with b-actin cDNA. Purified mRNA $(2 \mu \mathrm{g})$ was subjected to electrophoresis in a $1 \%$ agarose-formaldehyde gel for 1 $\mathrm{h}$ at $60 \mathrm{~V}$ and then for $2 \mathrm{~h}$ at $120 \mathrm{~V}$ in $1 \times$ MOPS buffer. mRNAs were transferred to a Gene Screen Plus Nylon membrane. The membrane was prehybridized for $4 \mathrm{~h}$ at $42{ }^{\circ} \mathrm{C}$ in $50 \%(\mathrm{v} / \mathrm{v})$ formamide, $10 \%$ sodium dextrin sulfate $(\mathrm{Mr} 500,000), 5 \times \mathrm{SSPE}, 10 \%(\mathrm{w} / \mathrm{v}) \mathrm{SDS}, 5 \times$ Denhardt's solution, and $100 \mathrm{mg} / \mathrm{L}$ denatured salmon sperm DNA. Then the membrane was allowed to hybridized with a probe for $\mathrm{P}^{53}$ that had been labeled with $\left[{ }^{32} \mathrm{P}\right]$-dCTP by the random priming method (Random Primer Labeling Kit protocol) at $42{ }^{\circ} \mathrm{C}$ for $24 \mathrm{~h}$ in the hybridization buffer, which was the same as the prehybridization buffer. The membrane was then washed twice at room temperature in $2 \times \mathrm{SSPE}$ for $15 \mathrm{~min}$ then twice for $30 \mathrm{~min}$. in $2 \times \mathrm{SSPE}$ and $2 \% \mathrm{SDS}$ at $65{ }^{\circ} \mathrm{C}$, and final two times in $0.1 \times \mathrm{SSPE}$ at room temperature for $15 \mathrm{~min}$. Washed membranes were exposed to x-ray film at $-80{ }^{\circ} \mathrm{C}$. For normalization of signals, membranes were reprobed with a cDNA probe for b-actin mRNA that had been labeled with [32P]-dCTP after stripping off the previously used DNA probe by boiling the membrane for $20 \mathrm{~min}$. in $0.1 \times \mathrm{SSC}$ and $1 \%$ SDS solution. (The compositions of buffers were as follows: TE buffer, $10 \mathrm{mM}$ Tris-HCl, pH 8.0, 1 mM EDTA; Tris-acetate buffer, 40 mM Tris-acetate, pH 8.0, 1 mM EDTA; PBS, $137 \mathrm{mM} \mathrm{NaCl,} 2$. $68 \mathrm{mM} \mathrm{KCl}, 8.07 \mathrm{mM} \mathrm{Na}_{2} \mathrm{HPO}_{4}, 1.47 \mathrm{mM} \mathrm{KH}_{2} \mathrm{PO}_{4}$; MOPS buffer, $20 \mathrm{mM}$ MOPS, $5 \mathrm{mM}$ sodium acetate, 1 mM EDTA, pH 7.4; SSPE, $10 \mathrm{mM} \mathrm{Na2PO4,} \mathrm{pH} \mathrm{7.4,} 150 \mathrm{mM} \mathrm{NaCl}, 1 \mathrm{mM}$ EDTA; $5 \times$ Denhardt's solution, $0.1 \%$ (w/v) Ficoll, $0.1 \%$ PVP, $0.1 \%$ BSA and SSC, $150 \mathrm{mM} \mathrm{NaCl}, 15 \mathrm{mM}$ sodium citrate).

\section{RESULTS AND DISCUSSION}

\section{Morphological and biochemical characteristics of apoptosis in VEC}

When confluent cultures of VEC were deprived of aFGF and serum, some cells started to round up and finally detached from the dish[7]. Several membrane vesicles, named as apoptotic bodies, were shed from the detached cells. The process of the formation of apoptotic bodies proceeded with a very low speed during apoptosis triggered by the deprivation of aFGF and serum. By contrast, when rattlesnake venom (from 2 to $10 \mu \mathrm{g} / \mathrm{ml}$ ) was added to the cultures of VEC, cells rapidly detached from the dish[8], and simultaneously, many apoptotic bodies were formed. After $8 \mathrm{~h}$, about $70 \%$ of cells became detached from the dish, accompanied with many apoptotic bodies (Fig 1 ).

The cells that had been deprived of survival factors ( $\alpha \mathrm{FGF}$ and serum) and that treated 
Gene expressions in apoptosis induced by rattlesnake venom

\section{Fig 1.}

The progress of apoptosis of VEC in two apoptosis inducing systems. Apoptosis (\%) were calculated as described in Materials and Methods. Black triangle, cells cultured in MCDB-104 medium deprived of aFGF and serum; black circle, cells similarly cultured in the presence of rattlesnake venom. The concentration of rattlesnake venom was $6 \mathrm{mg} / \mathrm{ml}$. Apoptosis (\%) of control VEC was zero. Means and SD (bars) from five independent experiments.

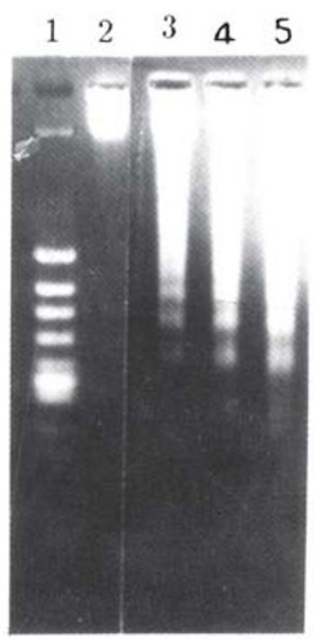

Fig 2.

DNA fragmentation assay of apoptosis of VEC as treated in Fig 1.

Lane 1, DNA markers (fragments of $\phi \mathrm{x}-174$ DNA, 79-1,057 bp);

Lane 2, DNA extracted from control cells; Lane 3, DNA extracted from cells deprived of aFGF and serum for $6 \mathrm{~h}$;

Lane 4, and lane 5, DNA extracted from cells treated with $6 \mu \mathrm{g} / \mathrm{ml}$ rattlesnake venom for 3 $\mathrm{h}$ and $6 \mathrm{~h}$, respectively.

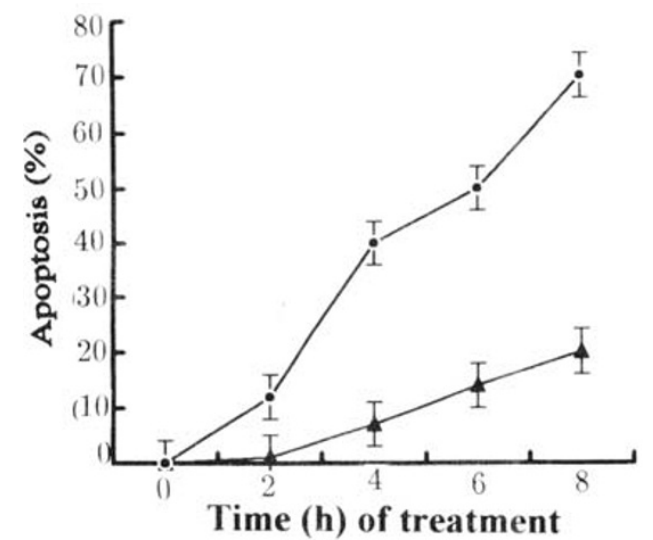

$\begin{array}{llll}1 & 2 & 3 & 4\end{array}$

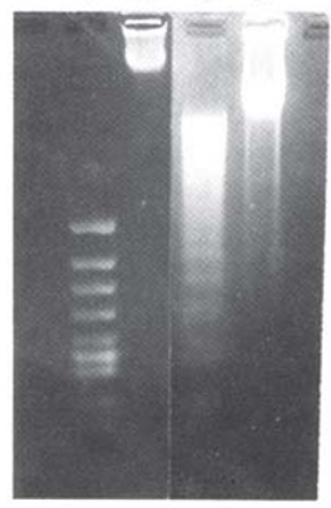

Fig 3.

DRB inhibition of DNA fragmentation in VEC induced by rattlesnake venom.

Lane 1, DNA markers (fragments of $\phi \mathrm{x}-174$ DNA, 79-1, 057 bp); lane 2, DNA extracted from control cells;

lane 3, DNA of cells treated with $10 \mu \mathrm{g} / \mathrm{ml}$ rattlesnake venom for $24 \mathrm{~h}$;

lane 4, DNA of cells treated with $25 \mu M$ $\mathrm{DRB}$ and $10 \mu \mathrm{g} / \mathrm{ml}$ rattlesnake venom for $24 \mathrm{~h}$.

with rattlesnake venom for $6 \mathrm{~h}$ were collected and the DNAs extracted respectively. Electrophoretic fractionation of DNA on an agarose gel revealed its fragmentation which is characteristic of apoptotic cell death (Fig 2).

\section{Involvement of gene expression in formation of apoptotic bodies in VEC}

It is interesting to know why the formation of apoptotic bodies in apoptosis induced by 

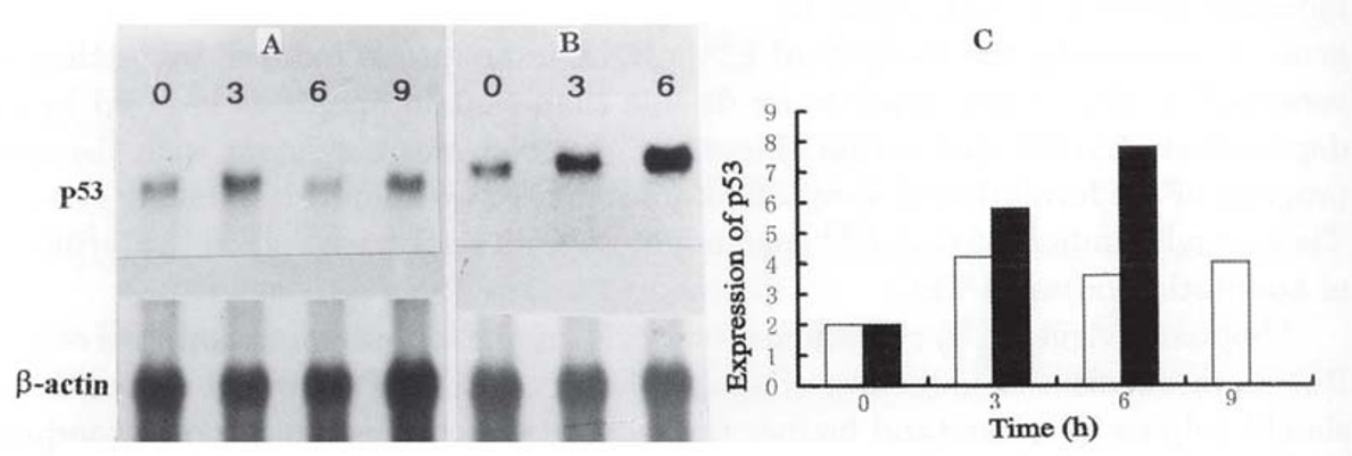

Fig 4.

Northern blot analysis and the relative level of the expression of $\mathrm{P}^{53}$ gene in the course of apoptosis of VEC in the two different inducing systems.

A: Cells deprived of aFGF and serum for $0 \mathrm{~h}$ (lane 0), $3 \mathrm{~h}$ (lane 3), $6 \mathrm{~h}$ (lane 6) and $9 \mathrm{~h}$ (lane 9) respectively. mRNA $(2 \mu \mathrm{g})$ in each lane was probed with $\left[{ }^{32} \mathrm{P}\right]$-dCTP by the random priming method.

B: Cells deprived of aFGF and serum were treated with $10 \mu \mathrm{g} / \mathrm{ml}$ rattlesnake venom for $0 \mathrm{~h}$ (lane 0 ), $3 \mathrm{~h}$ (lane

3 ) and $6 \mathrm{~h}$ (lane 6) respectively. mRNA (2 mg) of each lane was probed by the same method as in A.

$\mathrm{C}$ : The relative level of expression of $\mathrm{P}^{53}$ gene under the same condition as in A (open bars) and B (filled bars). The relative levels of gene expression were determined by densitometry of autoradiograms.

The result was a representative one from three independent reproducible experiments.

rattlesnake venom was so much faster than that in apoptosis induced by deprivation of aFGF and serum. The mRNA synthesis of VEC in the presence of rattlesnake venom was thus blocked by using a specific inhibitor of transcription, DRB. About $100 \%$ of cells treated with $10 \mu \mathrm{g} / \mathrm{ml}$ rattlesnake venom for $24 \mathrm{~h}$ became fragmentized into apoptotic bodies, but, almost all cells treated with both $25 \mu M$ DRB and $10 \mu \mathrm{g} / \mathrm{ml} \mathrm{rattlesnake} \mathrm{venom}$ for the same period remained round. These data suggested that gene expression was necessary for the formation of apoptotic bodies in VEC apoptosis.

When the nuclear fragmentation and DNA fragmentation were examined for the cells treated only with rattlesnake venom and those treated with both DRB and rattlesnake venom, the death of the former cells was clearly due to apoptosis, but in case of latter cells, DRB drastically inhibited the nuclear fragmentation and DNA fragmentation induced by rattlesnake venom (Fig 3).

The possible role of $P^{53}$ gene expression in the formation of apoptotic bodies in VEC

To confirm the involvement of gene expression in the formation of apoptotic bodies, the 
Gene expressions in apoptosis induced by rattlesnake venom

change of $\mathrm{P}^{53} \mathrm{mRNA}$ expression was followed in these two apoptosis inducing systems of VEC, with the results showing the increased expression of $\mathrm{P}^{53}$ gene. Interestingly, the increase of $\mathrm{P}^{53} \mathrm{mRNA}$ in apoptosis induced by rattlesnake venom (Fig $4 \mathrm{~B}, \mathrm{C}$ ) was much more drastic than that in apoptosis induced by the deprivation of $\alpha \mathrm{FGF}$ and serum (Fig $4 \mathrm{~A}, \mathrm{C})$ ), which was consistent with the rapid progress of the formation of apoptotic bodies in the two apoptosis inducing systems. These results indicated that $\mathrm{P}^{53}$ gene might have an important role in the formation of apoptotic bodies in VEC.

Apoptosis triggered by rattlesnake venom is unique to vascular endothelial cells[8]. But its mechanism of induction of apoptosis is not clear. The results reported here should help us to understand further the molecular mechanism of apoptosis induced by rattlesnake venom.

The formation of apoptotic bodies is a typical character of apoptotic cell death, however, how the processes are controlled is not known. In a recent report, $\mathrm{P}^{53}$ gene-deficient hepatocytes were found to be not able to form apoptotic bodies despite that IFN-g induced cell death in normal hepatocytes, which implied that $\mathrm{P}^{53}$ gene may play a major role in the induction of apoptotic body formation[6]. Our results reported here are in line with this notion.

\section{REFERENCES}

[1] Steller H. Mechanisms and genes of cellular suicide. Science 1995; 267:1445-9.

[2] Martin SJ, Green DR, Lotter TG. Dicing with death: dissecting the components of the apoptosis machinery. Trends Biochem Sci 1994; 19:26-30.

[3] Mcconkey D J, Orrenius S. Signal transduction pathway to apoptosis. Trends Cell Biol 1994; 4:370-5.

[4] Cohen J J. Apoptosis. Immunol Today 1993; 14:126-30.

[5] Simm A, Bertsch G, Frank H, Zimmermann U, Hoppe J. Cell death of AKR-2B fibrioblasts after serum removal: a process between apoptosis and necrosis. J Cell Sci 1997; 110:819-28.

[6] Kano A, Watanabe Y, Takeda N, Aizawa S, Akaike T. Analysis of IFN-g-induced cell cycle arrest and cell death in hepatocytes. J Biochem 1997; 121:677-83.

[7] Araki S, Shimada Y, Kaji K, Hayashi H. Apoptosis of vascular endothelial cells by fibroblast growth factor deprivation. Biochem Biophys Res Commun 1990; 168:1194-200.

[8] Araki S, Ishida T, Yamamoto T, Kaji K, Hayashi H. Induction of apoptosis by hemorrhagic snake venom in vascular endothelial cells. Biochem Biophys Res Commun 1993; 190:148-53.

[9] Lobb RR, Fett JW. Purification of two distinct growth factors from bovine neural tissue by heparin affinity chromatography. Biochemistry 1984; 23:6295-6.

[10] Jaffe EA, Nachman RL, Becker CG, Minik RC. Culture of human endothelial cells derived from umbilical veins. J Clin Invest 1973; 52:2745-56.

[11] Miao JY, Araki S, Kaji K, Hayashi H. Integrin b4 is involved in apoptosis signal transduction in endothelial cells. Biochem Biophys Res Commun 1997; 233:182-6. Received June-26-1998.

Revised June-21-1999. Accepted June-23-1999. 